\title{
Die prediking oor die historiese stof van die Ou Testament
}

FN Lion-Cachet, Potchefstroom

\begin{abstract}
The preaching of the historical books of the Old Testament Since there is a prevailing interest in preaching on Old Testament literature and sustained interest in the discussion of historical literature and homiletics, this article has been written in quest of guidelines for dynamic preaching on Old Testament historic literature. After a brief survey of the significance of historic literature and of preaching through the ages, a discussion of the essence of historic literature is presented. The proposed guidelines will emphasize the need for the formulation of a marked pericope; for awareness of the communication between God and man in any given framework; for the importance of revelation theology and for the Biblical focus on God. Furthermore these guidelines should contribute to the preaching of God's Word in present-day circumstances. Genesis 4 may serve as an example.
\end{abstract}

\section{INLEIDING}

Uit 'n steekproef wat gedoen is uit die preke wat in Die Kerkblad (19861987) verskyn het, blyk dit dat $40 \%$ van hierdie preke historiese stof uit die Ou Testament as teks gebruik het. Die betekenis van die historiese gedeeltes in die Ou Testament het heelwat probleme opgelewer (cf byvoorbeeld Hasel, 1982:97-115), sowel as die prediking self (cf Dijk, 1955:3975) en riglyne vir die Ou-Testamentiese prediking kan handig wees om, desnieteenstaande bogenoemde probleme, aan die eise wat prediking as bediening van die Woord stel, te voldoen.

Met die woorde van die Koning van die kerk: "Gaan dan heen, maak dissipels van al die nasies" (Matt 28:19a) in gedagte, word op die eise wat aan die prediking gestel word, gelet en moontlike riglyne gesoek wat tot die dinamiek van die prediking van die Ou-Testamentiese stof kan bydra. Die beoordeling sal gedoen word met die volle erkenning dat die Bybel die onfeilbare Woord van God is en dat alle wetenskaplike navorsing op 'n openbarings-historiese (openbarings-kognitiewe) wyse op dié openbaring bou.

Eerstens sal op die belangrikheid van die historiese literatuur gelet word en dan sal agtereenvolgens die problematiek wat rondom die prediking kan ontstaan en die wese van die historiese stof behandel word, om uiteindelik moontlike riglyne vir die prediking van Ou-Testamentiese historiese stof aan te dui. 
- Die Ou Testament vertoon 'n ryk verskeidenheid van literatuursoorte waarin die historiese stof, wetsbepalinge, geslagsregisters, en dokumente of dele daarvan, van die profetiese (en die apokaliptiese) en die liriese en die wysheidsliteratuur onderskei word (cf ' $n$ ander indeling van die stowwe in Eissfeldt. 1966 en Deist en Vorster, 1986). Dijk (1955:199) noem die Pentateug, die boeke van Josua tot Ester (in die Septuagint) en sekere gedeeltes van die profete (bv Jes 36 - 39, Jona en Dan 1 - 6) historiese stof. Volgens hom bevat die Pentateug ook wel tipies-simboliese stowwe.

* Die probleme rondom die aard van die geskiedenisdissipline, die historie van die Ou Testament en openbaringsgeskiedenis (die onderskeiding tussen historia sacra en historia revelationis) is al lank onder diskussie (cf Hasel, 1982:97-115 en Marsak, 1970). Von Rad onderskei tussen die geskiedenis van Israel soos dit verkry is deur die inoderne kritiese ondersoek en die geskiedenis van Israel soos dit in die Israelitiese geloof weergegee is (1963:107-108). Hasel (1982:108) wil die spanning wat daar in die verskillende beskouinge oor die aard van die twee sieninge is, probeer oorbrug en pleit vir 'n eenheid van facta en dicta, van feite en interpretasie, gebeure en woord of gebeure en betekenis. Sonder om op hierdie probleem dieper in te gaan (dit pas nie in die opset van hierdie artikel nie), word tot 'n groot mate by Hasel aangesluit. In die historiografie van die Ou Testament word dit wat werklik in die verlede gebeur het en wat God aan ons wou openbaar as 'n eenheid weergegee (cf Hasel, 1982:115). Ons het nie met mites en sages of die een of ander inkleding van geestelike gedagtes te doen nie, maar met werklike feite uit die verlede wat selektief aan ons meegedeel word sodat ons Gods openbaring in genade (en gerig) in die gang van die gebeure kan verstaan.

In hierdie openbaring in die geskiedenis maak God waarhede en feite in gebeurtenisse wat nog nie voorheen bekend was nie, aan die mens bekend. Gewoonlik word die woorde gâlâh (ni), râ'âh (ni) en jãda' (ni, pi, hitp) gebruik en dit het in die Ou Testament te doen met die teofanie, die wonder (in die gang van die gebeure) en die profesie (cf Bavinck, 1918:336, 360, 367).

^ In die bree chronologiese weergawe van die openbaringshistoriese gebeure en soos wat dit in die Ou Testament weergegee is (dws sonder 'n herstrukturering op grond van 'n histories-kritiese ondersoek), kan die gevolgtrekking gemaak word dat God Homself eers sprekend (soms word teofaniee genoem) en handelend in die wondergang van die geskiedenis geopenbaar het (die historiese gedeeltes van Genesis en Eksodus), daarna sy volk in 'n bepaalde lewensverband saamgebind en hierdie volks- en kultusverband gereèl het ('n groot gedeelte van Eksodus, die hele Levitikus en weer 'n deel van Numeri) en voor die intog in die beloofde land verder onderrig en op die betekenis van die onderrig gewys het (Deuteronomium). In hierdie openbaringswyse word Israel op die veelvuldige genade van die Jahweh gewys. Gedurig openbaar God Homself in sy verskyning en wonderwerking en op hierdie fondament word die vergadering van die volk en hulle onderrig gebou. Dit word dinamies in die huishouding van God en sy volk. 
So verloop dit ook in die Nuwe Testament. God openbaar Homself in Jesus Christus (die Evangelies), daarna word die kerk geïnstitueer (die Evangelies en Handelinge) en die onderrig volg in die Briewe en Openbaring. Bogenoemde onderskeidinge is natuurlik nie absoluut of ' $n$ onverbreekbare paradigma nie.

Tog is daar ' $n$ waarheidsmoment. In elke fase van die kerklike lewe kan iets daarvan gesien word. Die openbaringsgeskiedenis word grondliggend vertel, dan volg die verdere onderrig in die kerk. Bogenoemde is baie eenvoudig gestel en kan sekerlik op baie plekke verder ingevul word. Dit is egter merkwaardig dat die daadwerklike openbaring in die geskiedkundige gebeure (die spreke tot Abraham, die eksodus, die dood en opstanding van Christus) rundamenteel is vir die volk van God en die liggaam van Christus. Holwerda (soos aangehaal deur Greidanus, 1970: 131) sê: "History lays the foundation for dogma and ethics."

So val die klem op die openbaring in die gebeure in die geskiedenis. Dit is God se pedagogie. Hy het die mens nie met 'n stel redeneringe, definisies, en formules ingelig nie, maar met die tintelende, lewende beskrywing van sy bekendmaking in vroeer eeue sodat sy kinders, ook die heel eenvoudigste, kan weet wat Hy doen en wie Hy is (cf Veenhof, sj: 16). Die woorde en werke van ons Here Jesus Christus is dié blye boodskap. die kerugma, daarna volg die onderrig, die didaskalia.

Nie een van bogenoemde dimensies kan uitgelaat word nie. Geen aspek mag vervals of verabsoluteer word nie. Die valse kerk wil sy eie verhaal vertel en self tussen goed en kwaad onderskei (Genesis $3: 5$ ) of doen wat goed is in sy eie oe (Rigters $21: 25$ ). Israel het gedwaal toe hulle hul eie heiligdomme by Dan en Bet-El opgerig het en in stede daarvan om na die profete te luister, hulle doodgemaak het. Die kerk dwaal as die pous as die stadshouer van Christus gesien word wat met "goddelike" gesag uitsprake gee wat God nie in die geskiedenis gegee het nie; of as die Roomse Kerk met sy sakramente en seremonies homself as die enigste kerk beskou en Protestante vermoor en dan 'n Te Deum sing. ' $n$ Kerk verstar as dit wat God in die geskiedenis gedoen het, nie meer vertel word nie, of in 'n kerklike vorm ingedwing word of rasioneel dogmatisties aangebied word.

^ Die historiese gebeure is so nie alleen van grondliggende belang nie, maar die prediking van Gods wonderdade in die geskiedenis is van wesensbelang en word uitdruklik gebied.

Die woord 'âmar - "sê, praat, vertel" - is een van die woorde wat die meeste in die Ou Testament voorkom. 'âmar dui in die algemene taalgebruik die wyse van kommunikasie aan waarin een persoon sy gedagtes bekend maak sodat 'n ander dit mag hoor en verstaan en daarop kan reageer. As teologiese term word dit gebruik waar God Homself aan die mens openbaar (Deuteronomium $5: 5$ ), maar die Woord het ook dinamiese krag, want dit word gebruik van God se wyse van skepping, die proklamasie van sy bevele, die troos van sy bemoediging (cf Wagner. 1974:331-335).

In Deuteronomium 6 : 4 word die groot gebod gegee en dan volg die bevel 
dat die Israeliet dit by sy kinders moet inskerp (herhaal) en dat hy gedurig daaroor moet praat. "En as jou seun jou later vra en sē: Wat beteken die getuienisse en insettinge . . . dan moet jy aan jou seun sê 'âmar) : ..." - en dan volg eers die geskiedenis van God se handelinge met Israel voordat die roeping van die gelowige herhaal word (Deuteronomium $6: 20-25$ ). Dit is trouens 'n tipiese wyse waarin die verbond meegedeel word. Eers die historiese proloog en daarna die bepalings (cf Eksodus 20:2; Deuteronomium 1-3; 5:6; Josua 24:2-13).

In die Ou Ooste was die vertellings tot ' $n$ fyn kuns ontwikkel. Elke vertelling het sy eie vorm en struktuur gehad en 'n mens is elke keer verbaas om die ontwikkeling in die verhaal tot die ontplooiing te volg (die "intrige"). Dit was lewendige vertellinge sodat ons nie verbaas hoef te wees om die dialoogvorm oral teen te kom nie. Ons verneem selfs wat God by die skepping gesê het (Genesis $2: 26$ ). Tog is hierdie vertellinge mededelings van Gods openbaring in die geskiedenis en is dit so grondliggend dat die verdere opbou van Gods volk en hulle onderrig daarsonder nie verstaan kan word nie.

Die prediking van die historiese stof is onmisbaar in die dissipelmaking, gemeentebou, verdere onderrig en die formulering van Skrifwaarhede.

\section{DIE PROBLEMATIEK RONDOM DIE PREDIKING}

Om die probleem van die prediking van historiese stof goed te verstaan, is dit wenslik om 'n steekproef in die geskiedenis van die prediking (waarvan baie historiese stof verklaar) te maak en op die beklemtonings van die verlede te let. (Cf Dijk, 1955:3975: Ker, 1889:54-182: Parker, 1986; Skinner. 1973:23-31).

^ In die eerste twee eeue na Christus was die verkondiging 'n baie eenvoudige uiteensetting van die Woord. By Origenes (185-284) kry ons die eerste kenmerkende Christelike prediking. Hy vergader mense rondom hom en gee dan van elke woord in elke reël 'n eenvoudige verklaring. Die historiese, dogmatiese en geestelike aspekte word beklemtoon, maar as 'n geleerde van sy tyd wat met allerlei filofiese sienings te doen het, lê hy veral die klem op die geestelike aspekte. Die konkreet historiese word deur ' $n$ allegoriese verklaring vervang. Chrisostomus (347-407), die man met die goue mond, sien die hoorder raak en meen dat hy 'n besondere appèl tot hom moet rig. Die klem verskuif nou na die retorika en die preke word kunssinnig en aangrypend tot die hoorder gerig. Met Augustinus (354-430) kom daar weer besinning alhoewel hy nie die allegorie en die retorika heeltemal oorboord gooi nie. Hy hou hom egter by verklaring van die Woord. Die doel van die prediking is om te onderrig (docere), tot liefde te wek (delectare) en om tot diens te motiveer (movere).

Die Middeleeue ( $800-1200)$ was inderdaad donker. Die prediking het tot voorlesings van Latynse preke of homilieë verval. Hierdie homiliee het gewoonlik met die woorde "post illa verba textus" (na aanleiding van die woorde van die teks) begin. In die volksmond was hulle "postille" genoem. 'n Postille was sinoniem met iets droogs en baie lidmate het die kerk verlaat as die biskop met die voorlesing van 'n postille begin het.

In die Skriflig $1989,23(1)-23$ 
Die Reformasie word voorafgegaan deur die skolastiek. Thomas van Aquino (1225 - 1274) beklemtoon die onderrigkarakter van die prediking. Prediking word dan analities, dogmatisties en polemies. Die verstand het alles oorgeneem en wou alles verklaar. Terselfdertyd het die mistici hulle stem laat hoor. Ker (1889:126) merk heel gepas op: "If the scholastics were light without heat, the mystics were heat without light."

In die Reformasie kry ons weer 'n goeie balans. Luther (1483 - 1546) en Calvyn (1509 - 1564) wil voluit na die Skrif luister. In hulle verklaring en prediking vra hulle na die letterlike bedoeling van dit wat daar geskrywe staan. Dit beteken grammaties-historiese eksegese en die prediking van die hele boodskap van die Skrif. Luther het met volle oortuiging gestel dat die beste prediker die een is wat die Bybel die beste ken. Calvyn het tweekeer elke Sondag gepreek en elke dag elke alternatiewe week. Hy het boek na boek geneem en elke vers uit die hoof verklaar en toegepas. Teenoor hierdie meer analitiese metode was Luther die meester in sy kragtige en vloeiende prediking.

Die preekstyl in die protestante kerke het na die reformasie nie konstant in die rigting van Luther en Calvyn beweeg nie. Melanchton beklemtoon die onderwysende element en sy preke word leerredes. Die Piëtiste (0.a. Spener) dring daarop aan dat die vroomheid (ook van die prediker) en Christelike ervaring 'n plek moet kry en dit bring die verlies van die amptelike karakter van die prediking mee. In die Anglikaanse kerke in Engeland, wat deur die romantiek beinvloed was, het ' $n$ preek versmal tot 'n homilie wat later tot die sogenaamde Social Gospel-prediking ontwikkel. In die ontwikkelingslyn is daar natuurlik manne wat wil vashou aan eenvoudige Skrifprediking soos A Hyperius en William Perkins.

Die model van die prediking het steeds van tyd tot tyd en van persoon tot persoon gewissel en ou en nuwe strukture vertoon. Daar is nog Schleiermacher wat die gevoel in die religie beklemtoon of A Vinet wat soms die vader van die etiese prediking genoem word. $\mathrm{K}$ Barth oordeel dat die prediker alleen ' $n$ woord moet bring wat tog nooit die eintlike Woord kan wees nie, maar alleen ruimte vir die Woord van God moet skep om Homself in die hede mee te deel.

Sonder om te wys op die invloed van die ontwikkeling van die Ou-Testamentiese teologie (wat die aandag weer te ver van die onderwerp sal aflei) kan die aandag net gevestig word op die sogenaamde eksemplariese prediking. Die persone in die Bybelse geskiedenis word dan as modelle of voorbeelde ("examples") voorgehou. Abraham, Josef, Dawid, Salomo of Jeremia word as geloofshelde voorgehou en na aanleiding van hulle optrede word ons tot navolging van hulle optrede opgeroep. Die stryd rondom die geldigheid van hierdie metode het veral in Nederland in die jare 1930 - 1940 gewoed en het in die Gereformeerde Kerk heftige teenstanders, maar ook aanhangers gevind. Baie verdedigers van eksemplariese prediking het dit sekerlik nie eensydig beklemtoon nie. maar het daaraan wel 'n plek toegeken in die wye predikingsverband (cf Greidanus, 1970:56-120. d'Assonville, 1976:64-68). 
Bogenoemde is maar enkele voorbeelde van die probleme in die prediking. Daar kan nog by dogmatistiese prediking, wat sy wortels in die skolastiek het, of illustratiewe en "motto"-prediking stilgestaan word. In laasgenoemde word 'n leerstelling of een van die loci van die dogmatiek of dogma uit 'n historiese vertelling bewys. Die tema word dan 'n dogmatiese stelling ("motto") en die verklaring 'n redenering (cf Greidanus, 1970:35).

Wat word van die prediking van die historiese stof vereis? Dijk (1955:75) antwoord tereg: "Indien slechts aan deze voorwaarde wordt voldaan, dat is zij bediening van het Woord Gods, en geen sensasionele reportage of boeiende verhaaltjes-romantiek." In ons soeke om 'n antwoord te vind om in die bediening van Gods Woord aan bogenoemde te voldoen, wil ons eerstens kyk na die aard van die Bybelse geskiedenis

\section{DIE WESE VAN DIE HISTORIESE STOF}

God het Homself aan die mens bekend gemaak in die skepping, die onderhouding en bestiering van die skepping. Hy is die eerste oorsaak van alle dinge wat op die aarde gebeur en Hy bepaal die gang van die geskiedenis. In die Ou Bedeling (die bedeling van die Vader) het Hy aan die mens verskyn en met hom gekommunikeer in 'n verstaanbare taal, maar ook in die gewone en ongewone gang van die geskiedenis (die wonders). Hierdie openbaringe was waarneembare en werklik historiese gebeurtenisse (feite). Die historiese gebeurtenisse (veral die Godsverskynings en wonders) het nie alleen vir die mens die geleentheid gegee om God te leer ken nie, maar het die hele mens aangespreek en geaktiveer. Gedurende 'n teofanie of ongewone gebeurtenis was die mens vreesbevange (Genesis $15: 1$; Rigters $13: 22$, Matteus $28: 4$ - 5), maar dit was baiekeer die middel wat die mens tot geloof en aksie gedring het. Na die bevel van die HERE het Abram gehoorsaam weggetrek (Genesis $12: 4$ - 5), Moses het die HERE gevrees (Eksodus $3: 6$ ) en gedoen wat die HERE vir hom gesê het $(4: 18)$, Israel het die HERE gevrees en geglo (14:31).

As die historiese gebeurtenisse oorvertel en later opgeskrywe word, kan die aanvanklike aandoening en inpak in die proses van die mondelinge tradisie of historiografie verbleek. Die vertelling van 'n ooggetuie sprankel nog omdat die verteller iets van sy gewaarwording belewe in die vertelling. As 'n derde persoon dit beskrywe, kan dit weer eens van die glans van die oorspronklike gebeure verloor. Na Jesus se opstanding was die dissipels huiwerig om dit te glo en Thomas het bly twyfel al het hy dit betroubaar gehoor. Hy het eers geglo toe Jesus self aan hom verskyn. Dat hy geglo het, het natuurlik 'n dieper agtergrond, want dit is die werk van die Heilige Gees, maar dit lyk tog of daar iets van die werklikheid en warmte van Jesus se eerste verskyning verlore gegaan het selfs in die mond van ooggetuies.

Die wyse van oorvertel en van latere optekening is dus van die grootste belang. Die Heilige Gees het self die optekening van die historiese stof versorg, want Hy het die heilige mense wat oorvertel en opgeskrywe het, gedrywe (2 Pet 1:21). Die historiese gebeurtenisse is op so 'n wyse 
opgeskrywe dat dit die leser moet oortuig en tot geloof moet bring en 'n latere prediker moet waak om nie hierdie oortuigingskrag deur 'n swak preek te verdof nie.

Wat geskrywe staan, moet letterlik so verkondig word. Dit beteken nie dat die Skriftuurlike beskrywing letterlik ooit in alles met die werklikheid kan ooreenkom nie. Daar is 'n gaping tussen die gebeure en die geskrewe vertelling, maar die betekenis van die geskrewe gebeurtenis sal uit die teks met sy invullinge en weglatings, sy woordorde en beklemtoninge, sy vaaghede en duidelike tendense volkome aan die leser duidelik word. Hierby kan ons die woorde van Polman (sj: 185) byvoeg: en "dat het zoo wordt uitgelegd, gelijk het in die dagen algemeen werd verstaan".

Die historiese geskrifte kom veral in die torah, die profetiese geskrifte van Josua tot Konings en in die geskrifte Kronieke en Esra-Nehemia voor. Hierdie geskrifte kon 'n lang wordingsgeskiedenis gehad het. Die gang van die tradisie is maar dof. Daar was sekerlik vanaf die Eksodus ooggetuies, oorvertellings, bronne, verwerkings en aktualiseringe. Waarvan ons baie seker is, is dat ons die eindresultaat as 'n geheel uit die hand van die Heilige Gees ontvang het. Laat ons daarom waak om nie te probeer om die eintlike gebeurtenisse te rekonstrueer nie. "Moreover, this emphasis on the original facts, on the foundation, easily causes the preacher to look right past the most important redemptive-historical fact for preaching: the text,... We have only the text, and the preacher's task is to proclaim the text in conformity with the intention of its inspired author" (Greidanus, 1970:193).

Ons kan ook die teks as eindproduk preek en hoef nie in te gaan op die wordinggeskiedenis van die teks nie. As 'n mens die krag en invloed van water $\left(\mathrm{H}^{2} \mathrm{O}\right)$ in die menslike lewe wil bespreek, staan 'n mens tog nie net by ' $n$ beskrywing van wat waterstof $(H)$ en suurstof $(0)$ is, stil nie.

Ons het ook nie met die eksakte geskiedenisbeskrywing wat die gebeure as 'n geslote kontinuum of 'n ononderbroke ketting van oorsaak en gevolg, waarin alles verklaar kan word, en waarin daar geen plek vir God is nie, te doen nie (cf Hasel, 1982:172), "maar dat wij in de historie van Israel de openbaring Gods, zijne gedachten en zijn raad zouden verstaan" (Bavinck, 1918:41).

Dit raak die skopus van die Skrif. God wil Homself, en sy besigwees met sy skepping bekend maak. Hy doen dit so genoegsaam dat ons Hom kan leer ken en gered kan word. In die mond van 'n Oosterse skrywer word die logiese en chronologiese orde soms omgeruil. Ons het daarom probleme met die vraag van Saul oor wie Dawid is (1 Samuel $17: 58$ ) nadat Dawid al lank in Saul se diens was (16:14-23). Alles word ons net nie meegedeel nie, maar ons kan maar alte duidelik verstaan wat God bedoel.

Ons verneem alleen van 'n paar historiese gebeurtenisse wat vir die openbaring van belang is. Ander dinge lê op die periferie en dan is hulle soms nog uit fokus. Ons kan byvoorbeeld die getalle in Konings en Kronieke net nie rym nie. Dit gaan egter nie om die geskiedenis as 
sodanig nie, maar om openbaringsgeskiedenis. Die ou rabbies het daarom tereg van die torah ("onderrig") en die vroeere profete gepraat.

Die historiese en normatiewe gang van die historiese stof moet ook aangeraak word. Dit is gepas om weer te sê dat die optrede van Bybelse persone nie normatief is nie (cf die bespreking van eksemplariese prediking). Die imperatief vind ons in wat God beveel en nie wat mense doen nie. Die historiese gebeure is inderdaad gesagvol beskrywe. Ons moet egter in die lig daarvan dat ons met geselekteerde vertellings te doen het wat op die Godsopenbaring in Christus gefokus is, nie op grond van aangeleenthede wat op die periferie lê en wat uit fokus is en skynbaar mekaar teenspreek, wil konkludeer dat historiese gegewens onbetroubaar is nie. Die historiese gegewens bied geen notarieêle presiesheid nie (cf Greidanus, 1970:197-199 wat na Augustinus en Calvyn verwys; Bavinck, 1918:415; Helberg, 1973:48).

Dit is miskien goed om hier na die verslag van die Christian Reformed Church in 1961 te verwys: "By 'accuracy', 'inerrancy' and 'consistency' we should not in the first instance mean that the historical, psychological or phenomenological statements of Scripture conform precisely - as we today understand precision - to event, or circumstance or nature or parallel statement, but that they completely fulfil the Spirit's purpose for making these statements. This purpose, one must hasten to add, can only be discovered by diligent and believing exegis of Scripture. It is not to be posited before interpretation begins, but is to be learned solely from the Scripture itself' (cf Greidanus, 1970:201).

Dit is daarom ook beter om, as daar in vergelyking met ander tekste sekere oneffenhede is, die bepaalde teksinhoud soos wat dit in die Skrif gegee, is te verklaar en nie allerlei rasionele, maar tog subjektiewe harmonieërings voor te stel nie. As ons met Konings besig is hoef ons nie 'n oplossing voor te stel as ons teks met die in Kronieke verskil nie.

Hoe hoog is ons tog nie bevoorreg nie? Ons hoef nie die historie te herkonstrueer nie, ons hoef nie die teksgeskiedenis op te spoor om dit te preek nie, maar ons het 'n geinspireerde teks wat self vir ons die openbaring van die Heilige Gees is. Ons kan dus die historiese teks soos dit voor ons lê, preek. Die teks word ook nie oud nie, dit is elke oomblik die Heilige Gees wat in die werklikheid van ons lewe vandag aan ons die magtige dade van God vertel.

\section{MOONTLIKE RIGLYNE VIR DIE PREDIKING}

Dit is seker die roeping van die prediker om in die prediking van die historiese stof die verhaal so te vertel dat nie afbreuk gedoen word aan die lewendige getuienis van die Heilige Gees in die teks nie. Die prediking moet so een word met die teks dat dit wat vertel word die hoorder tot kennis en geloof kan beweeg (Johannes $20: 31$ ).

In ons eksegese gee ons gewoonlik aandag aan die taalkundige, kultuurhistoriese en openbaringshistoriese aspekte. In aansluiting daarby kan die volgende riglyne vir die prediking nuttig wees.

^ Die Ou-Testamentiese vertellinge vorm 'n groot eenheid. Tog kan 
kleiner eenhede onderskei word (die openbaring aan Abraham, of aan Dawid, of aan Hiskia) en dit kan weer onderverdeel word (die openbaring in die geskiedenis van die toringbou van Babel, die geskiedenis van die slag by die Skelfsee, of van Dawid en Batseba). Hierdie kleinere eenhede of perikope is elkeen op sy eie manier saamgeweef en het 'n eie boodskap. Dit is eerstens noodsaaklik dat ons 'n bepaalde eenheid of vertelling moet afbaken. Die eise wat een vertelling stel, maak dit moeilik om twee of meer perikope as "preekteks" te neem sonder om die boodskap van een vertelling te vermink. Die keuse van 'n te klein perikoop of teks kan egter weer probleme veroorsaak deurdat die onmiddellike Skrifverband verbreek word.

^ Die skruktuurontleding van die perikoop is belangrik, want dit gee 'n oorsig oor die samestelling van die verhaal en om die boodskap te formuleer. In die ontleding word die bepaalde tipe vasgestel en daarna die styl- en funksionele elemente (cf Lion-Cachet, 1987:50-55). In die preektekskeuse kan die hele perikoop of bepaalde verse of 'n vers gekies word. Calvyn het analities te werk gegaan en in die verklaring met die eerste teks begin en ononderbroke voortgegaan om vers na vers te verklaar. Die probleem is dan dat daar geen oorsig oor die geheel verkry word nie. 'n Mens stap die bos binne sonder om na die kaart te kyk.

Op grond van die struktuur, wat eintlik die grondplan van die verhaal gee en aantoon hoe die "intrige" ontplooi, kan 'n vers of verse gekies word wat 'n gepaste oorsig oor die verhaal gee. Elke vers is nie as preekteks geskik nie. Die struktuurontleding sal aantoon watter verse alleen die agtergrond of situasie skets en op die periferie lẽ en waar die besondere Godsopenbaring gefokus is. 'n Baie kort teks kan tot "motto"prediking aanleiding gee veral as die teks nog van die struktuur waarin hy ingebed is, losgemaak word. Die verkieslikste is miskien die prediking van 'n perikoop waarvan die struktuur vasgestel is en waarin 'n paar kernverse aangetoon word. So word die gevaar van 'n analitiese perikoopprediking en die van "motto"-prediking vermy. (Cf Trimp, 1980:5-9, 25-26; Smuts, 1982:40; Greidanus, 1970:217-218).

Die struktuur help ook om die tema of die boodskap van die perikoop te formuleer. Dit is wenslik om die tema as 'n kort uitspraak of oordeel te formuleer sodat die preek nie in 'n menigte mooi gedagtes verloop nie. Die preek kan later stelselmatig (puntsgewys) die stof in die perikoop behandel, maar dit sal dan nie noodwendig meen dat alles in die perikoop verklaar gaan word nie. Alleen dit wat organies by die preekteks (te) pas, sal verklaar word. Dit is seker wenslik om in die behandeling (of by 'n onderverdeling in punte) van die teks die orde van die teks of perikoop self te volg en nie meganies te vra wie, wat en waarom; of oorsaak, karakter en doel; of aanloop, verloop en afloop nie.

$\star$ In die verklaring van die teks is dit nodig dat voldoende aandag gegee word aan die wyse waarop God met ons kommunikeer. Die teks is in 'n menslike taal gegee en die gebeure waarin God spreek, is in 'n kultuurhistoriese raamwerk geplaas. Elke woord is van belang, want dit is versigtig deur die Heilige Gees gekies en as "woorde van wyse manne is soos prikkels", (Prediker 12:9-12) hoeveel te meer die woorde van 
God (cf Skinner, 1973:21). Die kultuurhistoriese agtergrondgegewens is belangrik, maar dit mag nooit die sentrale boodskap oorheers nie. Prediking is nie die mededeling van allerlei interessanthede nie, maar wil die boodskap in die geskiedenis so lewendig vertel dat mense kan glo. Die prediking moet ons so pak dat Abraham en Moses en Dawid nie vir ons as morele voorbeelde voorgehou moet word nie, maar asof ons saam met Abraham na God luister of saam met Moses sien hoe die volk deur die Skelfsee loop en ons gered word en om saam met Israel 'n oorwinningslied te kan sing. (Cf Greidanus, 1970:148).

$\star$ Daar is maar een fokus in die Skrif en dit is God self. God openbaar Homself as die Drie-enige God. In die ou bedeling val die klem op die een Goddelike wese, terwyl die nuwe bedeling ons die onderskeiding tussen die Persone van die Vader, Seun en Heilige Gees duideliker leer. As die Skrif dan Teosentries is wat is die plek van Christus? Daar is onder die teoloe 'n geskarrel om die plek van Christus in die prediking te formuleer. ' $n$ Preek moet mos Christosentries wees, want daar is ook geen ander Naam waardeur ons gered kan word nie (Handelinge $2: 12$ ). Hoekstra (1926:166-167) verkies om van twee sentrums te praat, naamlik van 'n Teosentriese en Christosentriese. Ander praat van Teologiese en Christosentriese prediking. Miskien is dit ook aanvaarbaar om van Teosentries in Christus te praat.

Christus is implisiet in die Ou Testament teenwoordig in die Drie-enheid en die tweede Persoon of die Seun kan in die deugde en werke van Jahweh herken word. So is Hy byvoorbeeld die Koning, Middelaar, Gesalfde en Verlosser. Daar is ook 'n Messiasverwagting en die belofte van sy koms. Enkele kere kan sekere Ou-Testamentiese figure as tipes van Christus gepreek word, maar dan alleen die wat uitdruklik in die Nuwe Testament so aangedui is. "We do not have the right to make and multiply 'tipes" " (Greidanus met verwysing na Van't Veer. 1970:85). Hier moet ons tog vir 'n Jesussentriese prediking waak. Elke teks word dan 'n heen$v$ 'sing na Betlehem of Golgota of daar word naarstiglik na 'n gelyke insident in die lewe van Christus gesoek.

$\star$ Die uiteensetting het natuurlik met meer as net die een bepaalde vertelling te doen. Die een vertelling waarmee ons besig is, is deel van 'n openbaringshistoriese geheel. Ons moet dus ook van die geheel kennis neem. Dit beteken nie alleen dat ons die optredes van sekere persone in die openbaringsgeskiedenis in die lig van die norme van die Skrif as geheel moet beoordeel nie, maar eintlik moet ons die plek van die gebeure in die voortgaande openbaringsgeskiedenis in samehang met die fokus van die Skrif vasstel. Ons kan byvoorbeeld die regverdiging of veroordeling van die feit dat Elimeleg uit Betlehem-Juda weggetrek het (Rut 1: 1) alleen uit ander Skrifgegewens verkry. Maar dit is vir ons belangriker om te weet dat Abram met reg in Genesis 12 in die nuwe land altare gebou het, maar dat die altaar wat die Rubenniete en Gaddiete oos van die Jordaan gebou het (Josua $22: 10$ ), ernstig bevraagteken is (22:16) omdat die res van die volk dit as verbondsbreuk beskou het en dit ook in lig van die sentralisasiebevel in Deuteronomium 12 as 'n dwaling beskou kan word. Die waarde van die altaar verdwyn in die 
nuwe bedeling. In die nuwe bedeling het die ou seremonies en die altaarbou hulle doel gedien en is afgeskaf (Handelinge 15).

Ons aanvaar vandag nie meer die vierpunt betekenisleer van die middeleeue nie (alle tekste het 'n letterlike, allegoriese, morele en anagogiese betekenis), maar daar sit wel in sekere gebeurtenisse en profesiee 'n dieper of geestelike sin (cf Trimp, 1980:15-16). "Deze exegese van het $O$ in NT onderstelt bij Jezus en de apostelen de gedachte, dat een woord of zin veel dieper beteekenis en veel verder strekking kan hebben, dan de schrijvers er bij vermoed of er in neergelegd hebben" (Bavinck. 1918:415). Die HERE belowe aan Dawid dat sy huis en sy koningskap tot in alle ewigheid sal bestaan (2 Samuel $7: 16$ ) en dit word in Christus vervul (Lukas 1 : 33). Dit is alleen moontlik om die dieper sin Skriftuurlik te ontdek deur uitdruklike Skriftuurlike getuienis, want die gevaar van subjektivisme is maar altyd besig om oor die skouer te loer.

Ons is lief om openbaringshistoriese lyne deur te trek (die koninkryksof die verbondslyn), maar die openbaring van God is so glansryk dat ons steeds daarvoor moet waak om nie sekere gedagtes wat nie daar is nie in 'n geskiedkundige gedeelte in te lees. Elke historiese vertelling het sy eie boodskap waarna ons biddend moet luister.

$\star$ 'n Kort woord oor die toepassing. In aansluiting by dit wat alreeds gesê is, kan herhaal en bygevoeg word dat prediking nie die vertelling is van wat in die verlede plaasgevind het nie, maar dit is die prediking van die teks as openbaring wat tot ons in ons eie bestaanstyd spreek. Die preek moet ons nie maar op die hoogte van die nuus van die dag bring nie, maar in die gebeure intrek met 'n oproep om te glo en om in die geloof "ja" te sê vir dade tot Gods eer en "nee" te sê vir die versoeking, dwaling en afgodery. "Preaching is a powerful happening that is pertinant to all human existence. It puts into operation a living power which always gains effect for good or ill" (Veenhof soos aangehaal deur Greidanus, 1970:156).

Die toepassing is daarom nie ' $n$ los aanhangsel wat soms niks met die Godsopenbaring te doen het nie. Soek tog geen oppervlakkige parallelle soos om die gebruik van die nagmaal te vergelyk met die woorde van Elia "Staan op, eet!" (1 Konings $19: 7$ ) of om na aanleiding van Numeri 22 : 25 - 28 waar Bileam die donkie geslaan het, teen dieremishandeling te waarsku nie. Die ideaal is sekerlik om so toepassend te verklaar (cf "applicationary explication" - Greidanus, 1970:229) dat ons saam met Josua sal neerval en God aanbid omdat Hy nou vir u en vir my sê: "Ek is die leërowerste van die HERE; Ek het nou gekom" (Josua 5).

\section{'N VOORBEELD}

As voorbeeld kan Genesis $4: 1-16$ dien. Vooraf moet gestel word dat die nodige taalkundige of grammatiese arbeid veronderstel word en dit sluit ook die gebruik van woordeboeke, grammatikas, kommentare en enige ander hulpmiddel tot die verklaring van die Skrif in.

Genesis 4 bied homself as 'n stukkie geskiedenis aan en dit word as sodanig verklaar. (Die vraag rondom die literatuursoort soos deur 'n histories-kritiese benadering verkry, word nie hier beredeneer nie.) 
$\star$ Daar bestaan verskil oor die begin en die einde van die perikoop of perikope in die hoofstuk. Fouche (1988:76-107) werk met twee moontlikhede, naamlik Genesis $4: 1$ - 16 en $4: 1$ - 26. As op die literatuursoorte gelet word, volg na die vertelling in $4: 1-16$ 'n kort inleiding en 'n geslagsregister met uitbreidings en vertakkings in $4: 17-22.4: 23-24$ is ' $n$ lied en $4: 25-26$ is weer ' $n$ geslagsregister met uitbreidings. Die moontlikheid dat ons hier met ' $n$ groot eenheid te doen het waarin verskillende literatuursoorte saamgevoeg is, kan nie ontken word nie. Daar is dus vir die prediker baie moontlikhede.

'n Praktiese moontlikheid is om $4: 1$ - 16 as perikoop te kies. Die Masoretiese teks impliseer so 'n perikoop. Dit word deur inleidende formules herken (cf "die mens het . . Eva beken" in $4: 1$; "Kain het sy vrou beken" in $4: 17$ - die begin van 'n nuwe perikoop - en "Adam het weer sy vrou beken" in $4: 25$ ). Die verhaal vorm 'n eenheid met Jahweh se handeling met Abel en Kain rondom die offers en dit wat daaruit voortgevloei het.

$\star$ Op grond van die funksie en die gedagtes in die sinseenhede kan die volgende struktuur verkry word (cf Fouché, 1988:77):

\section{1 - 2 Situasietekening}

3 - 4a Die offers voor Jahweh

$4 b-5$ Jahweh beoordeel die offeraars

6 - 7 Jahweh waarsku Kain

8 Kain verhard in sonde

9 - 12 Jahweh beoordeel die moord

13 - 15 Kain voor Jahweh

16 Situasietekening

Die perikoop vertoon 'n konsentrasiestruktuur wat rondom vers 6 - 8 wentel.

$4: 1$ - 2 gee die situasie van die twee kinders wat vir die mens gebore is. Hulle beroepe word ook genoem. Kain is die eersgeborene en moontlik die sterkere van die twee. In $4: 16$ word die situasie na die sonde van Kain geskets. Hy is 'n vlugteling wat ver van Jahweh gaan woon het.

In $4: 3$ - 4a bring Kain en Abel hulle offers voor Jahweh. Soos dit beskrywe word, is daar in die offerdaad en die offer (al was dit 'n graanen 'n vleisoffer) geen verskil tussen die twee nie. Die hartsgesindhede word nie vermeld nie. In $4: 13$ - 15 staan Kain weer voor Jahweh, maar hy offer nie. Jahweh kom hom egter tegemoet deur 'n teken aan hom te gee sodat hy nie doodgemaak sal word nie. 
In $4: 4 \mathrm{~b}$ - 5 word vermeld dat Jahweh die offeraars en hulle offers beoordeel het en in $4: 9$ - 12 verloop die beoordeling van Kain se optrede in 'n soort regsitting waarin hy tot verantwoording geroep en veroordeel word.

Die kern waaromheen die verhaal vertel word, is die waarskuwing van Jahweh en die verontagsaming van die waarskuwing deur Kain in $4: 6-8$.

Baie tekste kan in hierdie gedeelte as die "preekteks" gekies word, maar vers 6 - 8 vorm die hoogtepunt en die skeidingspunt in die verhaal. Alle ander tekskeuses moet uiteindelik rekening hou met Jahweh se waarskuwing en die feit dat daar desondanks die waarskuwing 'n moord gepleeg is.

$\star$ In die kommunikasie van God met die mens gee vers 6 - 8 die krisis tussen Jahweh en Kain. Nêrens word die konfrontasie so skerp geteken nie. Jahweh waarsku en roep tot regte optrede (geregtigheid) en Kain doen presies die teenoorgestelde. Hy pleeg die eerste moord. Vers 6 - 8 kan dus baie paslik as die "preekteks" dien.

In die buite-Bybelse literatuur is daar geen vergelykbare materiaal nie. Ons volle aandag is dus op die vertelling soos dit in 4:1-16 gegee is, toegespits. 'n Indringende sins- en woordeksegese is nodig.

$\star$ In die tekskeuse en die ontwikkeling van die preek moet die fokus van die Skrif steeds in gedagte gehou word. Die Skrifopenbaring gaan oor God. Die gerig oor die mens en die verlossing van die uitverkorenes is bedoel om God te verheerlik. Dit gaan dus nie om Kain en Abel nie, maar om Jahweh en Abel en veral om Jahweh en Kain. Die aanname en die verwerping van die twee broers word nie gemotiveer nie en hieroor is al bait gespekuleer. Sommige meen dat ons reeds met die uitverkiesing moet rekening hou en ander laat die klem op die sonde in die intermenslike verhoudinge val. Alhoewel Hebreërs $11: 4$ hierdie geskiedenis paslik toepas, gee dit tog ook aan ons die wese van die verhouding tussen Abel en Kain en Jahweh weer: "Deur die geloof het Abel 'n beter offer aan God gebring as Kain." (Cf ook 1 Joh $3: 12$.) Die wanverhouding van Kain tot God lei tot menslike wanverhoudings, onderlinge jaloesie en moord. Die toepassing moet nie eerstens gesoek word in die ambagsverskil of andersheid van die mense nie $(4: 1-2)$, of die aard van hulle offers (4:3-4a), of in 'n sosiale val nie (4:9-10), maar in die ongehoorsaamheid aan Jahweh.

$\star$ In 4 : 6 - 8 word Kain vooraf gewaarsku dat die sonde soos 'n wilde dier op hom lê en loer. As mens was hy net nie in staat om oor die sonde te heers nie. Hierdie stryd teen die sonde en die magteloosheid om te oorwin, kan in die loop van die openbaringsgeskiedenis gevolg word. Die versinsels wat die mens bedink, was maar altyddeur sleg (Gen $6: 5$; $8: 21$ ) en daar is per slot van sake niemand wat goed doen nie (Ps $14: 3)$. Daar is 'n Kain in elkeen van ons. Hierdie tragiese waarheid kom mooi uit in die Christelike worsteling wat Paulus in Romeine $7: 14$ - 26 bely. In $4: 6$ - 8 word min van die verlossingswerk van Jahweh meegedeel, maar in die waarskuwing lê reeds genade. Uit die Woord 
is dit ook duidelik dat dit nie die werke is wat salig maak nie, maar die genade van die HERE alleen. In die Romeine $7: 14$ - 26-perikoop waarin met die mag van die sonde geworstel word, is dit duidelik dat die verlossing in Christus is $(7: 25)$.

$\star$ Die toepassing moet nie gesoek word in die navolging van die optrede van Abel of in ' $n$ identifikasie met Kain as persoon nie, alhoewel daar waarheidsmomente is, maar in die wete dat die mens wat weet wat reg is en telkemale teen die kwaad gewaarsku word, tog so in die mag van die sonde is dat ' $n$ wonder (in Christus) hom alleen kan red.

\section{SLOTOPMERKING}

Die toepassing van die riglyne is nie ' $n$ resep wat meganies in elke geval sal inpas nie. Dit bly maar riglyne en elke perikoop sal 'n eie verklaring en verklaringsmetode self dikteer. Ons probeer in elk geval nie om in ons eksegese en prediking 'n paradigma op die verklaring van die Skrifgedeeltes af te forseer nie, maar om te luister wat God in sy Woord aan ons wil sê. Die riglyne kan miskien help dat ons beter luister en nie ons eie subjektiewe gedagtes in ons preke inforseer nie.

\section{BRONNELYS}

Bavinck, H. 1918. Gereformeerde Dogmatiek I. Kampen: Kok.

Bosman, HL. 1986. Die ontstaan en verstaan van die Ou Testament. (In Deist, F en Vorster, W, reds. Woorde wat ver kom. Kaapstad: Tafelberg.)

Burger, CW; Muller, BA \& Smit, DJ, reds. 1988. Riglyne vir die prediking oor die Genesisverhale. Kaapstad: NG Kerk.

Childs, BS. 1960. Myth and reality in the Old Testament. SBT 1/27. London: SCM

Childs, BC. 1974. The etiological tale re-examined. VT 24:387-397.

Coats, GW. 1983. Genesis with an introduction to narrative literature. Grand Rapids: Eerdmans.

Culley, RC. 1976. Studies in the structure of Hebrew narrative. Philadelphia: Fortress.

d'Assonville, VE. 1976. Die dwaasheid om te preek. Johannesburg: De Jong

Deist, FE. 1986. Verteltekste. (In Deist, F. Vorster, W, reds. Woorde wat ver kom. Kaapstad: Tafelberg.)

Deist, F. 1988. Laat my volk trek. Kaapstad: Tafelberg.

Deist, F \& Vorster, W, reds. 1986. Woorde wat ver kom, I. Kaapstad: Tafelberg

Dijk, K. 1955. De dienst der prediking. Kampen: Kok.

Eissfeldt, O. 1966. The Old Testament. An introduction. (Tr Peter R Ackroyd.) Oxford: Blackwell.

Frank, McConnell. 1986. The Bible and the narrative tradition. New York: Oxford.

Fouche, HL. 1988. Oergeskiedenis (Gen 1:1-11:26). (In Burger, GW, Muller, BA en Smit, DJ, reds. Kaapstad: NG Kerk.)

Greidanus, S. 1970 . Sola Scriptura. Kampen: Kok.

Hasel, GF, 1982. Old Testament theology: Basic issues in the current debate. Grand Rapids: Eerdmans.

Helberg. JL. 1973. Verklaring en prediking van die Ou Testament. Potchefstroom: PTP. 1980. Die Here regeer Pretoria: NG Kerk.

Hoekstra, T. 1926. Gereformeerde Homilitiek. Wageningen: Zomer \& Keuning.

Koole, JI. s.j. Verhaal en feit in de Oude Testament. Kampen: Kok.

Lion-Cachet, FN. 1987. In die werkswinkel van die Ou-Testamentiese eksegese. Potchefstroom: DSP

Marsak. LM. 1970. The nature of historical inquiry. New York: Holt. Rinehart and Winston.

Polman, ADR. Sj. Onze Nederlandsche Geloofbelijdenis I. Franeker: Wever

Schmidt. WH 1978. Dảbar. NDOT III:84-125.

Skinner, C 1973. The teaching ministry of the pulpit. Grand Rapids : Baker House 
Smuts, AJ. 1982. Preekteks of preteks. Skrif en kerk, 3:1:33-43.

Trimp, C. 1989. De preek. Kampen: Van den Berg.

Veenhof, C. Sj. Predik het Woord. Goes: Oosterbaan \& Le Cointre.

Von Rad, G. 1963 Old Testament theology, I. Edinburgh and London: Oliver \& Boyd.

Wagner, S. 1974. 'ámar. TDOT I:328-345. 